\title{
THE EXTRATERRITORIAL APPLICATION OF AMERICAN LAW: A METHODOLOGICAL AND CONSTITUTIONAL APPRAISAL
}

\author{
LEA BRILMAYER*
}

\section{INTRODUCTION}

The application of American law to litigation with international elements has provoked a storm of controversy. The debate is most pronounced in the field of antitrust law, although similar issues are present in areas such as securities regulation. As the United States faces not only increasing irritation on the part of certain foreign trading partners, but also occasional retaliatory legislation by foreign governments, it is natural to wonder how the present state of affairs came about.

Some of the causes of this controversy, and thus some of the cures as well, are methodological. This article focuses upon the interesting pattern of similarities and differences between the problems of the application of American law to international disputes and the problems of domestic "conflict of laws." As the domestic counterpart of the international law issue of the extraterritorial application of American law, conflict of laws offers insights and analogies which, surprisingly, have been rarely exploited or explored.' Conflict of laws has methodological problems, and experience in that field reinforces the conclusion that international law also should be methodologically addressed. ${ }^{2}$ Yet conflict of laws is also methodologically distinct in interesting ways, and some of these distinctions suggest avenues of approach to comparable problems in international law. In particular, fourteenth amendment due process claims have figured prominently in domestic conflicts litigation, but are virtually irrelevant to international conflicts litigation.

Copyright (C 1988 by Law and Contemporary Problems

* Nathan Baker Professor of Law, Yale Law School.

1. There are some prominent exceptions. See Lowenfeld, Public Law in the International Arena: Confict of Laws, International Law, and Some Suggestions for Their Interaction, 163 ReCueIL DEs Cours 315 (1979); Maier, Extraterritorial Jurisdiction at a Crossroads: An Intersection Between Public and Private International Law, 76 AM. J. INT'L L. 280 (1982); Meesen, International Law Limitations on State Jutisdiction, in Extraterritorial Application of Laws and Responses Thereto (C. Olmstead ed. 1984).

2. For this author's analysis of the methodological problems with domestic conflicts law, see Brilmayer, Governmental Interest Analysis: A House Without Foundations, 46 Онго Sт. L.J. 459 (1985). 
Because of the importance of this comparison to any analysis, a brief digression is necessary to delimit the respective domains of domestic choice of law and the extraterritorial application of American law. It is striking that there are two different Restatements that deal with these problems: the Restatement (Second) of Foreign Relations $\mathrm{Law}^{3}$ and the Restatement (Second) of Conflict of Laws. ${ }^{4}$ While the two Restatements seem to deal with similar problems, they virtually ignore each other's existence. ${ }^{5}$ It might appear that, given their respective titles, the Restatement of Conflicts governs conflicts of laws among the states, while the Restatement of Foreign Relations Law governs conflicts of laws between the United States and a foreign nation. This is not correct. Many domestic conflict of laws cases have an international flavor because they involve conflicts with the laws of another nation. ${ }^{6}$

Another possible explanation for the lack of commonality between the Restatements is that domestic conflicts law is municipal law, as opposed to the limits that are placed on municipal law by external sources of law such as international law. Thus, a distinction can be drawn between what a state wishes to do in terms of applying its law to disputes involving foreign elements, and what a state is entitled to do. ${ }^{7}$ While this is an important distinction, it is not the one at issue here. The Restatement of Conflicts addresses, among other things, the constitutional limits on choice of law, which are externally imposed rules and not municipal law. ${ }^{8}$ Conversely, the Restatement of Foreign Relations Law seems to indicate that its dictates of international law are American in origin. ${ }^{9}$ Similarly unhelpful is the suggestion that the Restatement of Foreign Relations Law deals with conflicts of "regulatory" or public law while the Restatement of Conflicts deals with private law. ${ }^{10}$ Whether or not that distinction is viable, it does not describe the different roles of the two Restatements. Some private law cases, such as Lauritzen $v$. Larsen, "fall under the Restatement of Foreign Relations Law.

The real difference between the two Restatements can be found in the source of the domestic law and not in the source of the law with which it conflicts. The Restatement of Foreign Relations Law deals with conflicts

3. (1965) [hereinafter Restatement of Foreign Relations LaW].

4. (1971) [hereinafter Restatement of Conflicts].

5. This point is noted in Maier, supra note 1 , at $285-86$

6. See, e.g., Homes Ins. v. Dick, 281 U.S. 397 (1930); Babcock v. Jackson, 12 N.Y.2d 473, 191 N.E.2d 279, 240 N.Y.S. 2d 743 (1963); Auten v. Auten, 308 N.Y. 155, 124 N.E.2d 99 (1954).

7. Dr. Meesen appears to be making essentially this distinction in a recent article. See Meesen, supra note 1 , at 38 (distinguishing between international law and domestic conflict of laws, decided under the lex fori). His purpose for making the distinction is not the differentiation between the two Restatements.

8. They are external, that is, to the source of the substantive law; federal law imposes constraints on state law.

9. See Restatement of Foreign Relations Law, supra note 3, § 131.

10. See, e.g., Lowenfeld, supra note 1, at 323-29. Lowenfeld argues that private law conflicts methods can usefully be brought to bear on public law cases. By private law, he seems to mean domestic conflicts law (such as that contained in the Restatement of Conflicts) while by public law he seems to mean cases governed by the Restatement of Foreign Relations Law.

11. 345 U.S. 571 (1953). This case was mentioned, for example, in the RESTATEMENT of Foreign Relations Law, supra note 3, § 403 reporter's note 2. 
between United States federal law and the law of another jurisdiction; the Restatement of Conflicts deals with conflicts between state law and the law of another jurisdiction, either another state or a foreign nation. This explanation suggests why the public/private law distinction might have been offered to differentiate between the two documents. Both the federal/state and public/private law distinctions can result in a case being dismissed once it is determined that local law will not apply, although for different reasons. Since states typically do not enforce the penal, tax, or regulatory rules of other states, ${ }^{12}$ the public/private distinction would explain the otherwise puzzling fact that in those cases where the Restatement of Foreign Relations Law (but not the Restatement of Conflicts) applies, lack of legislative jurisdiction entails lack of subject matter jurisdiction. ${ }^{13}$ The same consequence follows from the federal/state distinction between the two Restatements. In a case brought in federal court, adjudicative jurisdiction will typically depend upon whether there is a federal question, which in turn depends on whether there is local legislative jurisdiction. If foreign law governs, the case must be dismissed.

This explanation of the respective roles of the two Restatements raises a number of interesting points about the proper role of state and federal law. It underscores, for instance, that the Restatement of Foreign Relations Law restates choice of law principles that are themselves rules of federal law, while the Restatement of Conflicts addresses primarily state law. ${ }^{14}$ This is not shocking, although it could perhaps be argued either that both types of conflicts issues should be dealt with as questions of state law ${ }^{15}$ or that both should be questions of federal law. ${ }^{16}$ The importance of the federal law/state law dichotomy will be addressed again briefly in one of the final sections of this article. ${ }^{17}$

At this point, the similarities between the two types of conflicts issues are more important. Regardless of whether the source of domestic substantive law is state or federal, choice of law issues remain methodologically distinct in at least two respects. First, choice of law typically involves the interpretation of policies and interests underlying a statute that does not address the choice

12. This phenomenon is noted critically in Lowenfeld, supra note 1 , at 322-26, 346, 353, 359 (noting the "public law taboo" and criticizing the phrasing in terms of subject matter jurisdiction).

13. See generally' L. Brilmayer, An InTroduction to Jurisdiction in the American Federal SYSTEM (1986).

14. There are some federal principles subsumed under domestic conflicts of law, namely those based on the federal constitution or on federal statutes such as the full faith and credit implementing acts, 28 U.S.C. $\$ \S 1738,1738$ A (1982). That the Restatement of Foreign Relations Law is based on federal law is noted in its introduction. Restatement of Foreign Relations Law, supra note 3 , 82 , at 5 .

15. The argument would be based upon the Rules of Decision Act, 28 U.S.C. $\$ 1652$ (1982).

16. The argument would be based, in international cases, upon the prevention of state interference with foreign affairs. See, e.g., Zschernig v. Miller, 389 U.S. 429 (1968); Hines v. Davidowitz, 312 U.S. 52 (1941). Cf. also Asahi Metal Indus. Co. v. Superior Ct., 55 U.S.L.W. 4197. 4200 (1987). In the interstate context, it can also be argued that federal law should govern. Sep generally Baxter, Choice of Law and the Federal System, 16 STAN. L. Rev. 1 (1963). But sep Day \& Zimmerman, Inc. v. Challoner, 423 U.S. 3 (1975).

17. See infra text accompanying notes 118-120. 
of law issue. This is referred to below as the "silent statute" problem. Few substantive rules are accompanied by choice of law provisions; rather, the court charged with applying the rule must formulate choice of law standards. Second, the competing claims are based on the laws of another jurisdiction rather than another rule or principle from the same jurisdiction. This problem can be termed the "narrow nationalism" problem because it poses the question of whether other jurisdictions' interests ought to be taken into account, or only the interests of the forum. The argument presented here is that these two features of choice of law problems combine to pose an exceptionally severe test of the judicial function. They explain, first, a methodological trap that has ensnared courts operating in both contexts. Second, they account for some of the reasons that the Constitution has played a prominent role in one context but not the other.

II

\section{The Application of American law: A Methodological OVERVIEW}

The precise contours of American law in the international arena vary a great deal from one setting to another. The rules governing the extraterritorial application of the Fair Labor Standards Act seemingly bear little resemblance to those governing the antitrust acts or the Jones Act. Nevertheless, all share a common method; the relevant considerations are the same, as are their relative importance.

Legislative Intent: The first is the intent of Congress. The special relevance of congressional intent is established by such classic decisions as Alcoa ${ }^{18}$ and Lauritzen $v$. Larsen, ${ }^{19}$ but is also uniformly reiterated wherever the issue is discussed.20 The explanation usually given is that American courts have an overriding obligation to further the legislative mandate. ${ }^{21}$

18. United States v. Aluminum Co. of Am., 148 F.2d 416, 443 (2d Cir. 1945)

19. Lauritzen v. Larsen, 345 U.S. 571, 578-79 (1953).

20. Steele v. Bulova Watch Co., 344 U.S. 280, 282-83, 285-86, 290 (1952); Fley Bros. v. Filardo, 336 U.S. 281, $284-85$ (1949); Vermilya-Brown Co. v. Connell, 335 U.S. 377, 382-83, 389-90 (1948); Blackmer v. United States, 284 U.S. 421 , 437 (1932); United States v. Bowman, 260 U.S. 94, 97 (1922); Tamari v. Bache \& Co., 730 F.2d 1103, 1106-07 (7th Cir. 1984); Commodity Futures Trading Comm'n v. Nahas, 738 F.2d 487, 495 (D.C. Cir. 1984); Timberlane Lumber Co. v. Bank of Am., 549 F.2d 597, 609 (1976); Leasco Data Processing Equipment Corp. v. Maxwell, 468 F.2d 1326, 1334 (2d Cir. 1972); United States v. Firestone Tire \& Rubber, 518 F. Supp. 1021,1032 (N.D. Ohio 1981); Zenith Radio Corp. v. Matsushita Elec. Indus. Co., 494 F. Supp. 1161, 1180 (E.D. Pa. 1980).

21. Steele v. Bulova Watch Co., 344 U.S. 280, 285-86 (1952) ("The United States is not barred by any rule of international law .... there is no question of international law, but solely of the purport of the municipal law which establishes the duty of the citizen in relation to his own government" (quoting Skiriotes v. Florida, 383 U.S. 69, 73 (1941)); Commodity Futures Trading Comm'n v. Nahas, 738 F.2d 487, 495 (D.C. Cir. 1984) ("Federal courts must give effect to a valid. unambiguous congressional mandate, even if such effect would conflict with another nation's laws or violate international law."); United States v. Aluminum Co. of Am., 148 F.2d 416, 443 (2d Cir. 1945) (" $[\mathrm{W}] \mathrm{e}$ are concerned only with whether Congress chose to attach liability to the conduct outside the United States of persons not in allegiance to it. That being so, the only question open is whether Congress intended to impose liability, and whether our own Constitution permitted it to do so; as a court of the United States, we cannot look beyond our own law."). 
Presumptions: The second relevant consideration is the presumed reach of the statute in question. In certain statutes, Congress has specified the proper extraterritorial reach. ${ }^{22}$ More commonly, however, it has not. In the resulting exercise in statutory construction, courts often find little guidance in the legislative history about the extent to which the statute was designed to apply to transnational disputes. Facing this vacuum in the legislative history, courts have typically responded with presumptions about the likely territorial reach. For instance, some courts have held that legislation is presumed to apply only to events occurring within United States territory. ${ }^{23}$

International Law: The third relevant consideration is the presumed consistency of legislation with international law. Wherever possible, legislation is presumed to be consistent with international law. ${ }^{24}$ The Restatement of Foreign Relations Law has incorporated this maxim, ${ }^{25}$ in effect giving principles of international law the status of a presumed legislative intent.

Judicial Discretionary Doctrines: The fourth relevant consideration is the existence of judicial discretionary doctrines, of which there are two types, both controversial. One type pertains to the question of legislative

22. See, e.g., Fair Labor Standards Act of 1938, 29 U.S.C. $§ 213(\mathrm{f})$ (1982) ("The provisions of sections 206, 207, 211 and 212 of this title shall not apply with respect to any employee whose services during the workweek are performed in a workplace within a foreign country or within territory under the jurisdiction of the United States other than the following: a State of the United States; the District of Columbia; Puerto Rico; the Virgin Islands; outer Continental Shelf lands defined in the Outer Continental Shelf Lands Act (ch. 345, 67 Stat. 462 [43 U.S.C. \$\$ 1331]); American Samoa; Guam; Wake Island; Eniwetok Atoll; Kwajalein Acoll; Johnston Island.'); Age Discrimination in Employment Act of 1967, 29 U.S.C. \$ 626(b) (1982) (incorporates various provisions of the FLSA, including $\$ 213(f)$ cited above). For cases holding that ADEA does not apply extraterritorially, see Zahourek v. Arthur Young \& Co., 567 F. Supp. 1453 (D. Col. 1983), aff 'd, 750 F.2d 827 (10th Cir. 1984); Pfeiffer v. Wm. Wrigley. Jr. Co., 573 F. Supp. 458 (N.D. Ill. 1983), aff $d$, 755 F.2d 554 (7th Cir. 1985); Osborne v. United Technologies Corp., 16 Fair Empl. Prac. Cas. (BNA) 586 (D. Conn. 1977); Cleary v. United States Lines, Inc., 555 F. Supp. 1251 (D.N.J. 1983), aff'd, 728 F.2d 607 (3d Cir. 1984).

23. See, e.g., United States v. Mitchell, 553 F.2d 996, 1002 (5th Cir. 1977); Steele v. Bulova Watch Co., 344 U.S. 280, 285 (1952); Foley Bros. v. Filardo, 336 U.S. 281, 285 (1949); Blackmer v. United States, 284 U.S. 421,437 (1932); United States v. Bowman, 260 U.S. 94, 98 (1922); American Banana Co. v. United Fruit Co., 213 U.S. 347, 357 (1909); Tamari v. Bache \& Co., 730 F.2d 1103, 1107 n. 11 (7th Cir. 1984); Commodity Futures Trading Comm'n v. Nahas, 738 F.2d 487, 493 (D.C. Cir. 1984); Chitimacha Tribe v. Harry L. Laws Co., 690 F.2d 1157, 1168 (5th Cir. 1982); Pfeiffer v. Wm. Wrigley, Jr. Co., 573 F. Supp. 458, 459 (N.D. Ill. 1983), aff'd, 755 F.2d 554 (7th Cir. 1985); De Atucha v. Commodity Exch., Inc, 608 F. Supp. 510, 519 (S.D.N.Y. 1985); De Yoreo v. Bell Helicopter Textron, Inc, 608 F. Supp. 377, 379 (D.C. Tex. 1985); Zahourek v. Arthur Young \& Co., 567 F. Supp. 1453 (D. Col. 1983), aff'd, 750 F.2d 827 (10th Cir. 1984); Cleary v. United States Lines, Inc., 555 F. Supp. 1251,1257 (D. N.J. 1983), aff'd, 728 F.2d 607 (3d Cir. 1984).

24. See, e.g., Weinberger v. Rossi, 456 U.S. 25 (1982); Lauritzen v. Larsen, 344 U.S. 571, $577-78$ (1952); McCulloch v. Sociedad Nacional de Marineros de Honduras, 372 U.S. 101,121 (1963); Murray v. Schooner Charming Betsy, 6 U.S. (2 Cranch) 64, 118 (1804); Laker Airways v. Sabena, Belgian World Airlines, 731 F.2d 909, 950 n.155 (D.C. Cir. 1984); United States v. Hensel, 699 F.2d 18, 27 (1st Cir. 1983); Natural Resources Defense Council v. Nuclear Regulatory Comm'n, 647 F.2d 1345, 1357 (D.C. Cir. 1981); Federal Trade Comm'n v. Compagnie de Saint-Gobain-Pont-aMousson, 636 F.2d 1300, 1315, 1323 (D.C. Cir. 1980); Schroeder v. Bissell, 5 F.2d 838, 842 (2d Cir. 1925); Zenith Radio Corp. v. Matsushita Elec. Indus. Co., 494 F. Supp. 1161, 1178-79 (E.D. Pa. 1980).

25. Restatement of Foreign Relations Law, supra note $3, \S 134$. 
jurisdiction, counseling courts to take into account some other discretionary factors such as international comity. ${ }^{26}$ This is controversial both because the justification for judicial truncation of legislative wishes is unclear, and because the guidelines for exercising this judicial prerogative are so amorphous.

The second type pertains to adjudicative jurisdiction, which has an unavoidable impact on legislative jurisdiction. A court may find itself to be an inconvenient forum for adjudication of a dispute because of its international elements. ${ }^{27}$ This "forum non conveniens" power effectively limits legislative jurisdiction in those circumstances where it is anticipated that other fora would be unlikely to apply American law. Forum non conveniens dismissals are therefore vulnerable to accusations that they truncate legislative policies; however, this criticism may be misplaced because it seems that the majority of applications of the doctrine have been in cases involving common law, rather than statutory, causes of action. ${ }^{28}$

The Constitution: The final and least relevant consideration is the Constitution. The reasons that the Constitution has not served as an important consideration in this process will be discussed below. ${ }^{29}$ For the present, while it is commonly acknowledged that Congress is subject to constitutional limitations in these matters, ${ }^{30}$ this admission is usually made as a backhanded concession and has not resulted in any discernible restriction on the extraterritorial application of American law. ${ }^{31}$

The most important consideration governing the extraterritorial application of American law is a hybrid legislative/judicial construct. By and large, the issue is governed by presumptions which are judicially created and which often show the influence of international law. At the same time, these presumptions are presumptions about congressional intent and thus acquire the status of legislation. It is this hybrid nature of the dominant element in the methodology that accounts for a substantial part of the problem with our current situation. Presumptions of legislative intent are something of a Frankenstein monster: Easy to create, but hard to control.

\section{A. Statutory Construction and the Judicially Created Cul-de-Sac}

The problem with using presumptions of legislative intent relates to a difficulty in the construction of statutes, although it takes on a special flavor

26. Timberlane v. Bank of Am., 549 F.2d 597 (9th Cir. 1976).

27. See, e.g., Piper Aircraft Co. v. Reyno, 454 U.S. 235 (1981).

28. See, e.g., id. It has been argued that forum non conveniens might be used in international cases to reduce the friction inherent in extraterritorial application of U.S. law. Note, Forum Ion Conveniens and the Extraterritorial Application of U.S. Antitrust Lau, 94 YALE L.J. 1694, $1706-1714$ (1985).

29. See infra notes 47-101 and accompanying text.

30. See, e.g. , Lauritzen v. Larsen, 345 U.S. 571,579 (1953); Steele v. Bulova Watch Co., 334 U.S. 280, 282-83 (1952); Vermilya-Brown Co. v. Connell, 335 U.S. 377, 381 (1948); Timberlane Lumber Co. v. Bank of Am., 549 F.2d 597, 612 (9th Cir. 1976); Leasco Data Processing Equip. Corp. v. Maxwell, 468 F.2d 1326, 1334 (2d Cir. 1972); United States v. Aluminum Co. of Am., 148 F.2d 416 443 (2d Cir. 1945); United States v. Firestone Tire \& Rubber Co., 518 F. Supp. 1021 , 1032 (N.D. Ohio 1981).

31. In none of the cases cited in note 30 , supra, was application of U.S. law declared invalid. 
and urgency in the international context. The general difficulty is the inflexible position of a court charged with construing statutes, an inflexibility that may paradoxically cause it to reach results other than what the legislature would have wanted.

When a court decides whether a statute should apply to a situation which the statute does not address, it inescapably relies upon its own normative views. If one result seems more desirable than another, and the legislature has not expressed a preference, then it seems only reasonable to interpret the statute in accordance with the court's own view of what is desirable and just. After all, it is sensible to think that the legislature would have wanted this "better" result. The result is a peculiar combination of normative reasoning and deference to Congress, a normative view which is attributed to Congress even though it does not really express an actual congressional choice.

This process is clearly at work in the extraterritorial application of American law. Typically, a statute is silent as to its international scope. It seems sensible to interpret the statute in line with the court's own view of how far statutes ought to reach. In certain respects, this gives the court the best of both worlds. The court decides according to its own ideas of justice, usually shaped by principles and traditions of international law, but it need not assume explicit responsibility for having done so. The result is then couched in the language of deference to Congress.

Essentially the same process is at work in the application of state law to interstate conflicts. Under the modern interest analysis approach in conflict of laws, the primary objective is said to be the furtherance of legislative policies. ${ }^{32}$ As in the international context, there is rarely explicit guidance in the statutes; the functional equivalent of presumptions are employed. Interestingly, the content of these assumptions about the proper reach of legislative policy is very different from the content of the comparable presumptions in international law. For example, any notion that legislatures intend their rules to be applied territorially is completely lacking. ${ }^{33}$ Rather, the assumption is that legislatures act to protect their citizens wherever they go, a "passive personality" principle that has far fewer admirers in the international context. ${ }^{34}$

Despite these differences, the methodology is the same. In fact, Brainerd Currie entirely approved the reasoning and result in Lauritzen $v$. Larsen, ${ }^{35}$ apparently holding it out as a paradigm for courts to follow in the interstate context. ${ }^{36}$ Given these similarities, it is not surprising that the complaints of

32. See generally Brilmayer, supra note 2 .

33. B. Currie, Selected Essays 116 (1963) ("a legislature is not likely to append to any statute dealing with a specific problem any such rule as that the law of the place where the contract is made shall control").

34. Passive personality is recognized as a potential basis for jurisdiction, but denominates it "controversial" and "not generally accepted for ordinary torts or crimes." Restatement of Foreign Relations LaW, supra note 3 , § 402 comment $g$.

35. 345 U.S. 571 (1953).

36. B. CuRrie, supra note 33 , at 606 . 
overreaching in the international context have their counterpart in the interstate context. ${ }^{37}$ Both types of analysis are permeated by the philosophy of unilateralism-of adherence first to one's own rules of law, as opposed to the making of a neutral choice between local and foreign law. Further, both exhibit a common methodology, namely deference to legislative wishes coupled with the necessity for judges to define what those wishes are in terms of their own normative views.

While this method seems to offer judges the best of both worldsdeference and discretion combined-a problem arises when it appears that the initial statement of the scope of the law may need to be modified. For example, it is possible that an "effects" test was adequate in an earlier world of less interdependent markets, or with a business scene dominated to a greater degree by American corporations. ${ }^{38}$ The likelihood of a foreign corporation being large enough to have effects on American markets would then have been smaller. Today's world, however, contains many foreign corporations whose activities have effects on American markets solely as an incidental byproduct of their foreign activities.

Whatever the reason, it does seem clear that the current problems with antitrust law were not so severe forty or fifty years ago. How are courts to cope with these changes? The common law method typically formulates a rule for the case at hand, anticipating adjustments and accommodations later as circumstances change. Where judicial results are framed in terms of statutory construction, however, it is harder to adjust them to changed circumstances. The judicially created rule, while just a gloss, attains something of the status of a statute, and statutes are not as flexible as common law rules. The judge wishing to alter the contours of the effects test, for example, must apparently be willing to substitute his or her judgment for the judgment of the legislature.

The method of statutory construction works well enough when a court is first presented with a silent statute and therefore is writing on a clean slate. There is no legislative judgment to overrule; it is reasonable to construe the statute in light of principles of policy, justice, or international law. Once construed, however, the statute does not present a clean slate. The initial interpretation chokes off the continuing development of the law because judges are not supposed to disregard legislation. For the initial construction of the statute, the strategy works fine. When the time comes for further judicial elaboration, however, it appears that the court has been led down a blind alley. The difficulty is related both to the reliance on judicially created presumptions (the silent statute problem) and the interjurisdictional nature of the dispute (the narrow nationalism problem).

37. For a recent symposium on the current status of the modern choice of law learning, see 46 Oнго Sr. L.J. (1985) (proceedings of the A.A.L.S. meeting, Conflict of Laws section, Jan. 1985).

38. If all of the likely defendants are American corporations, imposition of American law is less likely to offend foreign nations. It is when foreign corporations doing business with other foreign corporations find themselves subjected to United States law that the worst problems arise. 


\section{B. Silent Statutes}

Something of the same woodenness occurs with legislative preferences as opposed to the employment of judicial presumptions about a silent statute. Here also, inflexibility is the long-range consequence. But there are two mitigating circumstances when the original decision was founded on actual inferences from legislative attitudes towards the problem. First, if the choice of law rule was statutory to begin with, then it is possible that many of its potential ramifications were adequately considered in its formulation. Legislatures are better situated than courts to lay out a code in advance. Because of the responsibility of courts to draw only principled distinctions, and because of their responsibility to frame a rule in terms of the case at hand, judicial rules are unavoidably less than complete codifications. Their reliance on principle makes them vulnerable to "slippery slope" problems; ${ }^{39}$ their avoidance of dictum means that the original principle, as stated, will probably not contain all of the necessary qualifications.

The second reason that this methodological problem is not as great where true statutory construction is involved is that if Congress addressed the problem in the first instance, there is some hope that Congress will take it up again when readjustment is needed. Of course, case reports abound with heartfelt pleas to Congress to rescue courts from archaic or incoherent statutes. ${ }^{40}$ This is as true in international law as in any other area of law. The problem is worse, however, when Congress has never addressed it at all and the decisions rest solely on judicial presumptions. It seems that congressional attention in the first instance might indicate a greater likelihood of congressional attention in the future.

\section{Narrow Nationalism}

These problems with judicial presumptions are general problems; it is not only in the international law context that we find silent statutes and judicial value judgments. Yet there are also reasons to believe that the special nature of international law exacerbates these methodological difficulties. A decision whether to apply American law should take into account both the costs and benefits of doing so. The benefits, however, are more easily cognizable under a methodology of statutory construction than are the costs. Thus, when the time comes to reassess the desirability of extending American law to disputes with international components, a court may feel inhibited from limiting the reach of a statute. It may take an unnecessarily narrow and nationalistic perspective.

To appreciate how this happens, assume that an initial decision has already been reached about the "presumably intended" reach of a statute. The decision reflects that judge's views with respect to both the nature of the policies underlying the statute and whether or not these policies apply to the

39. See generally Schauer, Slippery Slopes, 99 Harv. L. REv. 361 (1985).

40. See generally G. Calabresi, A Common law for the Age of Statutes (1982). 
instant case. The holding indicates that the desired benefits of the statute can best be achieved by applying it to cases of that sort. Once this conclusion is reached, it becomes difficult for a later court to deny those "benefits" out of deference to the needs of foreign nations. The reason is that the "costs" of the earlier decision are borne by outsiders.

The antitrust context provides an illustration. Simplifying somewhat for purposes of the example, assume that only an effects test limits the outer bounds of legislative intent. It is presumed, in other words, that Congress would wish the antitrust laws to apply whenever there is an anticompetitive effect in the United States, because it would wish to deter the anticompetitive impact on U.S. markets. Once the statute has been so construed, it becomes difficult for a court to curtail the reach of the statute. The reason is that the rationale for so doing would turn on avoiding offense to foreign nations. This rationale is not phrased in terms of American interests, but rather in terms of the interests of other states. And the power to restrict American law in order to further the interests of foreign nations is, to say the least, problematic. A court is unlikely to substitute its foreign policy judgment for a congressional judgment under any circumstances, but especially to further foreign interests. Since congressional intent has already been declared to require application, there is no principled basis for later limitation. Respect for local democratic institutions requires the effectuation of American policies, and expansionist tendencies have preempted the high moral ground.

This is particularly apparent when put into an historical framework. The objections of other nations are likely only to become clear after the commitment to the expansionist mode of statutory interpretation has been made. The result is that these pressures will come too late to be taken into account in formulating the presumption of statutory scope. They will inevitably be framed instead as the "costs" of the congressional policy. Once viewed in this light, it will be an uphill battle to obtain recognition for arguments to restrict jurisdiction. The restrictive arguments will be seen as disagreement with legislative policy and, moreover, as motivated by a desire to minimize the costs imposed on other nations. The judicial response to arguments framed in such terms is likely to be: "Take your objections to Congress."

Aside from the fact that courts do not consider themselves authorized to promote the interests of foreign nations, there is an additional problem with judges responding to such considerations. Concerns of international comity are not likely to be explicitly and directly embodied in any particular statute. Rather, they are general concerns that inform many different sorts of enactments, but are not necessarily the motivating force behind any one specific enactment. There is therefore no special reason why a court would find such considerations in the legislative history of the particular domestic statute it is construing. Lacking explicit guidance in the substantive statute being construed, a court is likely to reiterate the common maxim that the 
judicial branch is not adept at making foreign policy. ${ }^{41}$ While the policies in favor of extending the law are likely to loom large, and the benefits of doing so will seem direct, the policies counseling moderation are likely to be amorphous and to be embodied in many different enactments but not pointedly in any one. The selfish gains of extending the law are short-lived and apparent. The long-range benefits of restraint may be just as important, but harder to define precisely. Foreign policy, in other words, involves more politics than principle. While comity is probably a priority in Congress, it is difficult for courts to formulate standards to take comity into account.

Thus, a court might find itself stretching the law in slavish pursuit of congressional goals to an extent that Congress would not desire. It is not possible to examine the antitrust laws and determine the "proper" amount of deference to foreign nations. A standard of deference does not inhere in the antitrust laws themselves, and there is no other authoritative source from which deductions can be made. The flexibility and discretion that Congress might itself employ in setting a standard for the extraterritorial application of its antitrust laws cannot easily be determined by the courts.

This analysis is borne out by the treatment of recent efforts to cut back on antitrust jurisdiction. There are two sources of dissatisfaction with American expansionist tendencies, one practical and one theoretical. The practical impetus behind these efforts to restrict American law is the strong negative reaction of foreign parties and governments. The very source of the political pressure makes judicial reform less likely, however, to the extent that it suggests that restrictions would be based on something other than American interests in seeing the antitrust laws enforced. The theoretical impetus behind these efforts is a principled adherence to international law, particularly the multilateralist traditions which counsel respect for the interests of other states. Again, the emphasis on the needs of other states only makes matters worse from the judicial perspective.

The role of these considerations in actual decisions is apparent in Laker Airways $v$. Sabena. ${ }^{42}$ In explaining its refusal to balance the interests of other nations, Judge Wilkey's opinion makes clear the relative importance of congressionally defined interests and judicial solicitude for the interests of foreign nations:

The suggestion has been made that this court should engage in some form of interest balancing, permitting only a "reasonable" assertion of prescriptive jurisdiction to be implemented. However, this approach is unsuitable when courts are forced to choose between a domestic law which is designed to protect domestic interests, and a foreign law which is calculated to thwart the implementation of the domestic law in order to protect foreign interests allegedly threatened by the objectives of the domestic law. ... An English or American court cannot refuse to enforce a law its political branches have already determined is desirable and necessary. . . . Given the inherent limitations of the Judiciary, which must weigh these issues in the limited context of adversarial litigation, we seriously doubt whether we could adequately chart the

41. See generally L. Henkin, Foreign Affairs and the Constitution 206 (1972) (describing "doctrines of special deference").

42. 731 F.2d 909 (1984). 
competing problems and priorities that inevitably define the scope of any nation's interest in a legislated remedy. . . . Despite the real obligation of courts to apply international law and foster comity, domestic courts do not sit as internationally constituted tribunals. Domestic courts are created by national constitutions and statutes to enforce primarily national laws. The courts of most developed countries follow international law only to the extent it is not overridden by national law. . . . Judges are not politicians. The courts are not organs of political compromise . . [and] both institutional limitations on the judicial process and Constitutional restrictions on the exercise of judicial power make it unacceptable for the Judiciary to seize the political initiative and determine that legitimate application of American laws must evaporate when challenged by a foreign jurisdiction. ${ }^{43}$

An identical drama has been played out in the context of interstate conflict of laws. Here, the modern approaches speak in terms of "interests." Once a judicial holding declares what a state's interests are, these achieve the institutionally superior status of legislative command. In the eyes of interest analysts, it virtually then becomes treason for a state court to respond to any other consideration. Respect for another state's interests is countermajoritarian in that it neglects the wishes of the forum state's elected superiors. Rules which would cabin the assertion of these interests are branded as "metaphysical" in the same sense as is international law. It is "law" without a positive law source. ${ }^{44}$

\section{The Paradox of Delegation}

The situation described above is really very paradoxical, in both the interstate and international arenas. A comparable problem arises whenever one agency is charged with carrying out the wishes of another but is given insufficient guidance. If it phrases its decisions in terms of the wishes of its superiors, then the resulting inflexibility may cause it to be unable to decide as those superiors might actually wish.

The first half of the paradox lies in the fact that the rules which later constrain a court's authority are judicially created in the first instance. The effects test and the interest analysis approach to conflict of laws are not legislatively directed. Rather, they are judicial efforts to arrive at sound results. Yet because the general background includes statutory directives, the jurisdictional issue is framed in terms of statutory construction. Thus, while the cul-de-sac is of judicial making, it cannot easily be judicially corrected. The suppositions of local policy, against which the interest of foreign states or nations are necessarily aligned, are judicial suppositions and nothing more.

The second half of the paradox lies in the fact that the interests of foreign states or nations might very well be thought important by the legislature itself. Where legislatures do speak to choice of law issues, they typically do not extend their power to the utmost. ${ }^{45}$ This seems particularly true with

43. 731 F.2d at 948-54.

44. See generally Brilmayer, Interest Analysis and the Myth of Legislative Intent, 78 MicH. L. REv. 392 (1980).

45. For example, to my knowledge no state legislature has asserted legislative jurisdiction to the limits of the Constitution, as some have with regard to adjudicative jurisdiction. 
Congress, which obviously is aware of and sensitive to foreign policy concerns. Any action which will impact on foreign countries is undertaken with at least an awareness of the possibility of retaliation and reprisal, and sometimes this consideration will be influential.

The paradox of delegation is that because of institutional decisionmaking constraints, the decisionmaker who has been delegated the authority to decide may decide differently than the institution whose instructions it is charged with following. This is a common phenomenon; the range of interests which the delegated decisionmaker considers may be narrower than the interests that the delegating decisionmaker would have consulted. Another example consists of institutional trustees who are charged with investing money for trust beneficiaries. Typically, they are limited in their investment options, so that they may neither invest in risky ventures nor take "extraneous" concerns into account in making the choice. Thus, for instance, a trustee might be reluctant to divest profitable assets in South Africa because of its fiduciary responsibilities, despite the fact that the beneficiary would be free to do so and might very well exercise that option.

Similarly, federal courts are charged with applying state law in diversity cases as the state courts would. To the extent that this means consulting the relevant statutes and precedents, a federal court reaches the same result as a state court. State courts, however, have the power to overrule themselves. Since federal courts are not entitled to overrule state court decisions, the result is that the federal court version of state court justice may be more wooden than the state court's version. ${ }^{46}$

The most obvious solution to the problem would be to expand the range of considerations that the decisionmaker may rely upon to include all considerations that the institutional superior might invoke. In the context of international choice of law decisions, this would mean that in its initial solution to the problem of extraterritorial scope, a court should formulate a precise and sensible rule that incorporates the proper amount of deference to foreign interests, and does not overstate the scope of United States interests. Then no further readjustment would be needed. At the initial stage, it is methodologically easier to respond to considerations of comity in determining the relevant "legislative intent" because a court is writing on a blank page. When a court uses a presumption against extraterritorial application, for example, it relies upon comity notions by imputing them to Congress.

Yet, while it is obviously advantageous for a court to "get it right the first time," it is too much to hope that courts always will. If nothing else, there is the problem of changed circumstances; the real world rapidly changes with respect to any rule that might be formulated. There is also the impossibility of anticipating all of the problematic factual variations in advance. Flexibility

46. See generally P. Bator, P. Mishkin, D. Shapiro \& H. Wechsler, The Federal Courts and the Federal Srstem 708-10 (1973). 
is necessary and, from a broader perspective, it is certainly appropriate. But within the institutional confines of the interpretation of a particular statute, presumed statutory construction leads to a methodological dead end.

\section{III}

\section{The Role of the Constitution}

Regarding the methodological problems with presumptions of statutory intent, the international context is strikingly similar to the interstate context. Regarding certain other methodological issues, the two contexts are rather different. In particular, they differ with regard to the relative prominence of constitutional limitations.

In the interstate context, constitutional challenges to the application of forum law are not successful as frequently as they once were. ${ }^{47}$ The application of local law is upheld in situations where it would, undoubtedly, once have been reversed; 48 so much is recognized by the Supreme Court. ${ }^{49}$ Nevertheless, constitutional argument continues to play a prominent role in conflict of laws adjudication. The scholarly literature, in addition, pays as much attention to constitutional limits as it ever did. ${ }^{50}$ Thus, while constitutional limits have different contours than they used to, they are far from dead.

In the international context, by contrast, the Constitution plays virtually no role at all. The Supreme Court has never invalidated the extraterritorial application of federal law on constitutional grounds. ${ }^{51}$ In fact, none of the Court's decisions on extraterritorial application even seriously discuss the constitutional issues. ${ }^{52}$ The most attention these decisions ever give to the issue is a backhanded reference to the Constitution at the outset of the discussion about congressional intent. ${ }^{53}$ For example, in Alcoa Judge Hand

47. Compare Allstate Ins. Co. v. Hague, 449 U.S. 302 (1981) (choice of law controls) with New York Life Ins. Co. v. Dodge, 246 U.S. 357 (1918) (law of place of contracting governs).

48. See, e.g., R. Crampton, D. Currie, \& H. Kay, Conflict of Laws 403-51 (3d ed. 1981) (outlining history of constitutional development of choice of law).

49. Allstate Ins. Co. v. Hague, 449 U.S. at 308-14 (It is no longer true that a single state is entitled to apply its law.)

50. For a survey of scholarly reaction to the Hague case, see J. Martin, Conflict of Laws: Cases and Materials 338-42 (2d ed. 1984).

51. Cf. Timberlane Lumber Co. v. Bank of Am., 549 F.2d 597, 608 n.12 (9th Cir. 1976) (jurisdiction rarely found lacking).

52. Continental Ore Co. v. Union Carbide and Carbon Corp., 370 U.S. 690 (1962); Lauritzen v Larsen, 345 U.S. 571 (1953); Steele v. Bulova Watch Co., 344 U.S. 280 (1952); Foley Bros. v. Filardo, 336 U.S. 281 (1949); Vermilya-Brown Co. v. Connell, 335 U.S. 377 (1948); Blackmer v. United States, 284 U.S. 421 (1932); United States v. Sisal Sales Corp., 274 U.S. 268 (1927); Thomsen v. Cayser, 243 U.S. 66 (1917); United States v. Pacific and Arctic Ry. and Navigation Co., 228 U.S. 87 (1913); United States v. American Tobacco Co., 221 U.S. 106 (1911); American Banana Co. v. United Fruit Co., 213 U.S. 347 (1909).

53. See, e.g., Lauritzen v. Larsen, 345 U.S. 571 , 579 (1953); Steele v. Bulova Watch Co., 344 U.S. 280, 282-83 (1952); Vermilya-Brown Co. v. Connell, 335 U.S. 377, 381 (1948); Timberlane Lumber Co. v. Bank of Am., 549 F.2d 597, 612 (9th Cir. 1976); Leasco Data Processing Equip. Corp. v. Maxwell, 468 F.2d 1326, 1334 (2d Cir. 1945); United States v. Firestone Tire and Rubber Co., 518 F. Supp. 1021,1032 (N.D. Ohio 1981). 
wrote, "the only question open is whether Congress intended to impose the liability, and whether our own Constitution permitted it to do so."54 One might think that this statement initiated discussion of two points: statutory construction and constitutional interpretation. Nonetheless, the constitutional point never really resurfaced in the opinion.

Similarly, the Restatement of Foreign Relations Law recognizes that the Constitution limits American foreign relations powers. ${ }^{55}$ It never develops this point as to choice of law, however, despite the fact that some of its proposed limitations on American law, such as the reasonableness requirements, ${ }^{56}$ might find constitutional support. ${ }^{57}$ The secondary literature likewise is virtually silent on this issue. ${ }^{58}$ Most telling, however, is that constitutional arguments rarely have been advanced in the briefs of parties resisting application of American law. ${ }^{59}$ One wonders what lies behind this conspiracy of silence.

In part, this inattention to constitutional issues merely highlights the methodology of the presumption of statutory construction. Precisely because the interpretation is based upon presumed and not explicit congressional intent, the courts have great latitude to shape the outer contours of the extraterritorial application of American law. Since their notions of fairness find expression at this stage of the method, it is unlikely that the result of the interpretive process will offend their views on constitutional propriety. Constitutional analysis becomes, in fact, virtually redundant.

The same cannot be said for the extraterritorial application of state law. While this issue also is shaped by presumptions, there are at least two reasons why the interpretive process does not anticipate the constitutional discussion and render it unnecessary. First, in the interstate context the intellectual school propounded presumptions of construction that were both highly aggressive and somewhat dubious. For example, they relied in essence upon the "passive personality" principle which has found less support in American

54. United States v. Aluminum Co. of Am. 148 F.2d 416, 443 (2d Cir. 1945).

55. See, e.g., Restatement (Second) of Foreign Relations Law $\$ 721$ (Tent. Draft No. 6, 1985).

56. Id. $\$ 403$

57. Reasonableness is an important concept in interstate jurisdiction. See, e.g., R. WeIntraub, Commentary on the Conflict of Laws 503, 505-06, 517 (2d ed. 1980) (suggesting reasonableness test and citing cases).

58. For an interesting discussion of the Constitution in international disputes, see Label, The Limits of Constitutional Power: Conflicts Between Foreign Policy and International Law, 72 V. L. REV. 1071 (1985). The author's argument is different from mine in several respects, however. For one thing, he is concerned with public and not private international law. For another, his conclusion is that international law is to some degree constitutionally compelled; mine does not depend on international law in any way.

59. See, e.g., Brief for Petitioner, Lauritzen v. Larsen, 345 U.S. 571 (1953); Brief for Petitioner, Steele v. Bulova Watch Co., 344 U.S. 280 (1952); Brief for Petitioner, Foley Bros. v. Filardo, 336 U.S. 281 (1949); Brief for Petitioner, Vermilya-Brown Co. v. Connell, 335 U.S. 377 (1948); Brief for Respondent, United States v. Sisal Sales Corp., 274 U.S. 268 (1927); Brief for Petitioner, Thomsen v. Cayser, 243 U.S. 66 (1917); Brief for Respondent, United States v. Pacific and Arctic Ry. and Navigation Co., 228 U.S. 87 (1913); Brief for Respondent, United States v. American Tobacco Co., 221 U.S. 106 (1911); Brief for Respondent, American Banana Co. v. United Fruit Co., 213 U.S. 347 (1909). But see Brief for Plaintiffs, Dresser Indus., Inc. v. Baldridge, 549 F. Supp. 108 (D.D.C. 1982). 
foreign relations law. ${ }^{60}$ They also claimed that territorially-based distinctions violate equal protection. ${ }^{61}$ When the courts adopted the methodology, they brought in all of its baggage at the same time, including such presumptions. It is small wonder that the method precipitated a virtual civil war within the ranks of constitutional conflicts scholars. ${ }^{62}$ The presumptions relied on in the international context are less likely to provoke constitutional challenge. ${ }^{63}$

Second, in the interstate context the statutory construction issue is a matter of state law, while the constitutional issue is a matter of federal law. Where the Supreme Court reviews a lower court decision applying local law, it does not have the option of merely reinterpreting the statute; the Court has no authority to contradict state courts on issues of state law. ${ }^{64}$ The only device the Court may employ for limiting the reach of local law is constitutional invalidation. As between the two, the usual preference would be to base decisions upon statutory construction, for even outside the international/interstate context, prudential considerations favor modest interpretation of statutes over an aggressive interpretation which forces the constitutional issue. ${ }^{65}$ The greater attention to constitutional issues in the interstate context may simply indicate the unavailability of this preferred method for limiting the extraterritorial application of local law.

Under this analysis of the relative dearth of constitutional holdings in the international context, it may be expected that constitutional argument will become more important in the future. The reason relates to the discussion earlier about the inflexibility inherent in the presumptive interpretation methodology. ${ }^{66}$ Once the outer limits of the applicability of American law are established, it is no longer possible to use statutory construction to perform an essentially constitutional function. To do so would require admitting that the earlier decisions about the intended reach of the statute were mistaken. As there would be no basis in the legislative history or the statutory language for this reinterpretation, the decision could not be cast as furthering legislative wishes. The true rationale would have to lie elsewhere, such as in the recognition that the original interpretation might have been stated too broadly, given the court's own view of a desirable result. If a court cannot

60. Restatement of Foreign Relations Law, supra note 3, $\$ 402$ comment $\mathrm{g}$.

61. B. Currie, supra note 33, at 123, 146, 162.

62. A general discussion of the method and its critics can be found in any standard reference book on conflicts. See, e.g., L. Brilmayer, supra note 13, at 229-243.

63. In particular, they tend to rely on the presumption that the law's application is territorial, which is more conservative than either interest analysis or the "better law" approach, when foreign law can be applied without warning

64. Murdoch v. Mayor of Memphis, 87 U.S. (20 Wall) 590, 626 (1874) (To support the general proposition that the Court will not review judgments of state courts that rest on adequate and independent state grounds, the Court stated that "The State courts are the appropriate tribunals . for the decisions of questions arising under their local law, whether statutory otherwise.").

65. Ashwander v. TVA, 297 U.S. 288, 341, 347 (1936) (Brandeis, J., dissenting in part). In acknowledging the basic judicial duty to avoid decisions on constitutional grounds, Justice Brandeis declared that the Court would not pass upon a constitutional question where a decision could be reached on some narrower ground.

66. See supra notes $18-31$ and accompanying text. 
then write an opinion to the effect that it now can see that Congress really wanted something else, then it will be forced to rely upon the Constitution, the only remaining source of limitations.

To attribute judicial policy decisions to Congress in the first place, however, persists in posing problems. It has already been seen that the original hybrid legislative/judicial decision thwarts later efforts to restrict its scope because of its legislative nature ${ }^{67}$ neither common law alteration nor statutory reinterpretation seems a feasible means for reassessing the extraterritorial application of American law. Unfortunately, the judicial aspect of the hybrid decision also confounds later efforts at constitutional retrenchment because the original decision which established the problematic contours is also something of a constitutional precedent. Since the statute was presumably interpreted so as not to provoke constitutional issues, the interpretation which was adopted presumably does not offend the Constitution. Thus, although there may have been little or no explicit analysis of constitutional doctrine, constitutional argument seems foreclosed by the original holding. Because the initial holding supposedly represented both statutory and constitutional law, there is neither a statutory nor constitutional basis for later restriction.

This will be made clearer by a concrete illustration. The previous section considered the difficulties of a common law court attempting to revise the effects test once it becomes ensconced as the preferred congressional solution. ${ }^{68}$ It has been noted that courts cannot truncate congressional policies, particularly for reasons of foreign policy concerns or in order to advance the interests of foreign states. ${ }^{69}$ However, constitutional analysis is also thwarted because when the effects test was formulated it was presumably influenced by the desire for an interpretation that would not offend constitutional limitations. Essentially, the effects test was approved as passing constitutional muster in the case in which it was originally adopted. ${ }^{70}$ While the Supreme Court is not completely bound by such implicit constitutional holdings, it may nonetheless be less receptive to constitutional arguments because of these earlier decisions, and certainly the lower courts may find these implicit holdings to be persuasive.

The methodological cul-de-sac therefore extends even into the constitutional arena. Perhaps it explains why, as an historical matter, constitutional arguments have not been more prominent. It does not, however, justify continuing to ignore them. It is open to the Supreme Court to address the role of the Constitution in the international conflict of laws. We turn to that issue now: Does the Constitution apply?

It seems, at least prima facie, that the Constitution ought to limit the extraterritorial application of American law. The most obvious source of

67. See supra p. 186.

68. See supra text accompanying notes $32-46$.

69. See supra p. 20-22.

70. United States v. Aluminum Co. of Am., 148 F.2d 416 (2d Cir. 1945). 
limitations is the fifth amendment due process requirement, although there are other, less obvious, limitations. ${ }^{71}$ Due process is emphasized initially because two of the limits that might restrict a state's right to apply local law in the interstate context are inapplicable to the international application of American law. These include the commerce and full faith and credit clauses. The commerce clause has been used to invalidate the application of a state's anti-takeover statute to transactions occurring in substantial part in another state. ${ }^{72}$ However, it does not apply to limit congressional power in the international context because it is a grant of power to Congress and not a restriction on the exercise of power that otherwise exists. ${ }^{73}$

The full faith and credit clause is also not relevant. The reason is not (as with the commerce clause) that the source of authority being challenged is federal rather than state. The full faith and credit clause imposes requirements on federal exercises of power, at least in the context of judgments. ${ }^{74}$ Rather, the reason is that the alternative source of law is international. The clause imposes a duty of comity only with regard to the laws or judgments of states; its protection does not extend to laws of other countries. ${ }^{75}$ It is also possible that even if it did apply, it would not pose any threat to extraterritorial regulation. In the interstate context, it has been read to have minimal significance, merely duplicating the protections of the due process clause. ${ }^{76}$

Of the clauses that limit state power, only due process remains. When the source of challenged authority is federal, rather than state, these due process limits are found in the fifth rather than the fourteenth amendment; but in most contexts, it is not clear that this should matter. ${ }^{77}$ The current treatment of several analogous situations suggests that federal legislative jurisdiction ought to be limited by due process. The three analogous situations are: constitutional limits on state adjudicative jurisdiction in the international context; constitutional limits on state legislative jurisdiction in the international context; and constitutional limits on federal adjudicative jurisdiction in the international context. These analogous problems are represented in the following table, along with the problem presently under

71. See infra notes 122-126 and accompanying text. I am indebted to Harold Koh for sharing with me some of his ideas on such limits.

72. Edgar v. Mite Corp., 457 U.S. 624 (1982). See also Brown-Forman Distillers Corp. v. New York State Liquor Auth., 106 S. Ct. 2080 (1986).

73. The commerce clause limits the states only because their actions may have an impact on a federal power that is constitutionally granted; there is no comparable power with which the application of federal law might conflict.

74. See, e.g., Allen v. McCurry, 449 U.S. 90, 95 (1980).

75. Aetna Life Ins. Co. v. Tremblay, 223 U.S. 185, 190 (1912) (The full faith and credit clause of the Constitution does not extend to judgments of foreign states or nations and the Court, absent a treaty, has no jurisdiction to review a state court judgment on the ground that it failed to give full faith and credit to a judgment of a court of a foreign country.).

76. Allstate Ins. Co. v. Hague, 449 U.S. 302 (1981) (plurality opinion).

77. The primary difference between the two involves the differential treatment of aliens, which is more likely to be permissible if done by Congress. 
consideration, namely the constitutional limits on federal legislative jurisdiction in the international context.

\begin{tabular}{|l|l|l|}
\hline \multirow{2}{*}{ Source of Authority } & \multicolumn{2}{|c|}{ Type of Jurisdiction } \\
\cline { 2 - 3 } State & Judicial & Legislative \\
\cline { 2 - 3 } & 14th Amend. & 14th Amend. \\
\hline Federal & 5th Amend. & 5th Amend. \\
\hline
\end{tabular}

The upper left hand corner represents the limits on state adjudicative jurisdiction in the international context. Of course, everyone is familiar with the limits on state adjudicative jurisdiction in the domestic context. Those limits, also founded on the fourteenth amendment, are the focus of such famous decisions as International Shoe v. Washington, ${ }^{78}$ Hanson v. Denckla, ${ }^{79}$ and Shaffer $v$. Heitner. ${ }^{80}$ The test is one of "minimum contacts" and "fair play and substantial justice." 81 However, the identical test has been employed when the alternative forum is another nation, as opposed to another state. ${ }^{82}$ Such cases as Helicopteros Nacionales de Colombia ${ }^{83}$ make this clear. This is perhaps mildly surprising given that one basis for limitations of adjudicative jurisdiction is deference to alternative fora, ${ }^{84}$ and, at least under the full faith and credit clause, foreign nations receive less deference than other states. ${ }^{85}$ Furthermore, it has been argued that under a theory of "jurisdiction by necessity" plaintiffs should be allowed to sue in the United States if they would otherwise have to travel to another country to litigate. ${ }^{86}$ The principle seems to be settled, nonetheless, that the usual minimum contacts standard applies. In particular, the jurisdiction by necessity argument has not received a warm response from the Court. ${ }^{87}$

State legislative jurisdiction in the international context is, likewise, limited by the Constitution. Again, the cases with which we are most familiar are those limiting state legislative jurisdiction in the interstate context. ${ }^{88}$ Nonetheless, occasional cases address the issue in the international arena. Home

78. International Shoe Co. v. Washington Office of Unemployment Compensation and Placement, 326 U.S. 310 (1945).

79. Hanson v. Denckla, 357 U.S. 235 (1958).

80. Shaffer v. Heitner, 433 U.S. 186 (1977).

81. International Shoe Co. v. Washington Office of Unemployment Compensation and Placement, 326 U.S. at 316.

82. Koster v. Automark Indus., 640 F.2d 77 (7th Cir. 1981).

83. Helicopteros Nacionales de Colombia v. Hall, 466 U.S. 408 (1984).

84. World-Wide Volkswagen Corp. v. Woodson, 444 U.S. 286, 293-94 (1980).

85. Home Ins. Co. v. Dick, 281 U.S. 397 (1930).

86. Helicopteros Nacionales de Colombia, 466 U.S. at 419 n.13.

87. Id.

88. See, e.g., Order of United Commercial Travelers v. Wolfe, 331 U.S. 586 (1947); John Hancock Mut. Life Ins. Co. v. Yates, 299 U.S. 178 (1936); Hartford Accident and Indem. Co. v. Delta and Pine Land Co., 292 U.S. 143 (1934); Bradford Elec. Light Co. v. Clapper, 286 U.S. 145 (1932); New York Life Ins. Co. v. Dodge, 246 U.S. 357 (1918); McCluney v. Joseph Schlitz Brewing Co., 649 F.2d 578 (8th Cir. 1981), aff'd mem., 454 U.S. 1071 (1981). 
Insurance $v$. Dick ${ }^{89}$ is the best example. While over fifty years old, this decision continues to be cited by the Court with approval. ${ }^{90}$ As with the limits on adjudicative jurisdiction, the test for constitutionality does not seem to vary from the interstate to international contexts; by its citations of Home Insurance v. Dick in interstate cases the Court has seemed to suggest that the tests are the same. ${ }^{91}$

The lower left corner of the matrix presents a somewhat more interesting problem. ${ }^{92}$ These cases exemplify the limits on federal adjudicative jurisdiction in the international context. In the search for examples of this phenomenon, one is tempted at first to list cases such as Insurance Corp. of Ireland. ${ }^{93}$ In that case, the Supreme Court discussed the constitutional limits on the federal court adjudication of an international dispute. Such examples do not really count, however. In most situations, federal courts are limited by the restrictions on the long arm jurisdiction of the states in which they sit. ${ }^{94}$ Such restrictions are simply a function of the Erie ${ }^{95}$ doctrine and the Federal Rules of Civil Procedure ${ }^{96}$ and are not imposed for any constitutional reason.

One must, therefore, restrict one's search to cases where such doctrinal limitations are inoperative. It is only where Congress has provided for nationwide or worldwide service of process that the Erie doctrine and federal rules do not apply. This occurs in many of the substantive contexts which have been important also in the development of extraterritorial legislative jurisdiction, namely antitrust and securities laws. ${ }^{97}$ Although the Supreme Court has not addressed the issue, the lower courts seem uniformly to have assumed that the fifth amendment limits congressional attempts to provide adjudicative jurisdiction. ${ }^{98}$ In some respects, the fifth and fourteenth amendment tests may not be identical; for instance, contacts with the nation, rather than with a particular state, can be considered relevant. ${ }^{99}$ But this variation is consistent with the existence of some constitutional limitation, and it furthermore reflects the common principle that an individual must have contacts with the sovereign that is attempting to assert authority.

89. Home Ins. Co. v. Dick, 281 U.S. 387 (1930).

90. Allstate Ins. Co. v. Hague, 449 U.S. 302, 309 (1981) (plurality opinion).

91. Id. at 309-11.

92. See supra table p. 29.

93. Insurance Corp. v. Compagnie de Bauxites, 456 U.S. 694 (1982).

94. See, e.g., Arrowsmith v. United Press Int'l, 320 F.2d 219 (2d Cir. 1963).

95. Erie R.R. v. Tompkins, 304 U.S. 64 (1938).

96. FED. R. Civ. P. 4.

97. See, e.g., The Sherman Antitrust Act, 15 U.S.C. $\S \S 12,13,14-19,20,21,22-27$ (1982); The Securities Act of 1933, 15 U.S.C. $\$ 77$ (1982); The Securities Exchange Act of 1934, 15 U.S.C. $\$ 78$ (1982).

98. Kramer Motors, Inc. v. British Leyland, Ltd., 628 F.2d 1175 (9th Cir. 1980); Paulson Inv. Co. v. Norbay Sec., Inc., 603 F. Supp. 615 (D. Or. 1984); Staffin v. Greenberg, 509 F. Supp. 825, 831, 832 (E.D. Pa. 1981), aff'd, 672 F.2d 1196 (3d Cir. 1982); Alco Standard Corp. v. Benalal, 345 F. Supp. 14, 24, 25 (E.D. Pa. 1972); Oxford First Corp. v. PNC Liquidating Corp., 372 F. Supp. 191, 198-203 (E.D. Pa. 1974).

99. Staffin v. Greenberg, 509 F. Supp. 825, 831 (E.D. Pa. 1981), aff'd, 672 F.2d 1196 (2d Cir. 1982); Alco Standard Corp. v. Benalal, 345 F. Supp. 14, 24, 25 (E.D. Pa. 1972). 
This brings us to the problem case, namely the constitutional limits on the application of federal law to cases with international elements. As noted above, the Court has on several occasions stated in dictum that such assertions of legislative authority must satisfy the Constitution. ${ }^{100}$ But, as also noted, it seems never to have taken the possibility of failing to meet the Constitution's requirements seriously. ${ }^{10 t}$ Should it be assumed that the fifth amendment is relevant? Drawing on the other cells in the matrix, it might be argued that legislative jurisdiction is sometimes limited in the international context. Furthermore, federal assertions of jurisdiction are also sometimes limited. Why then should not the Constitution limit federal legislative jurisdiction?

At this point, it seems that the prima facie case has been made. There is at least a plausible argument for recognizing constitutional limits on the extraterritorial application of American law. The focus next must be to determine whether there are good reasons for treating federal legislative jurisdiction differently from other assertions of sovereign power in the international context. Three possible arguments come to mind. First, the congressional power over foreign affairs may be such as to render judicial scrutiny inappropriate. Second, nonresident aliens may have fewer constitutional rights than American citizens. Third, there may be something anomalous about giving the Constitution greater extraterritorial application than a federal statute.

1. Congress and Foreign Affairs. One clear difference between invalidation of state choice of law in the international context and invalidation of federal legislative jurisdiction lies in the congressional control over foreign affairs. It seems at least arguable that Congress should have greater leeway in deciding upon the scope of federal statutes than the states do with state statutes, because the grant of contitutional power to Congress explicitly includes the regulation of international relations. ${ }^{102}$ State assertions of power, in contrast, have on occasion been invalidated precisely because of their international implications, intruding upon the federal prerogative respecting foreign relations. ${ }^{103}$

This argument can be carried one step further to preclude all judicial scrutiny whatsoever of the exercise of foreign affairs powers by Congress. The political question doctrine, one offshoot of the Article III "case or controversy" limitation, ${ }^{104}$ removes certain issues from the scope of judicial review. ${ }^{105}$ Furthermore, this doctrine has been found to be applicable to certain aspects of presidential and congressional power in the international

100. See supra notes 51-54 and accompanying text.

101. Id.

102. U.S. Const. art. $1, \S 8, \mathrm{cl} .3$.

103. Japan Line, Ltd. v. Los Angeles, 441 U.S. 434 (1979); Zschernig v. Miller, 389 U.S. 429

(1968); Hines v. Davidowitz, 312 U.S. 52 (1941).

104. See generally L. BriLmayer, supra note $13,80-111$.

105. L. Henkin, Foreign Affairs and the Constitution 208-16 (1972). 
context. ${ }^{106}$ If accepted, such an application of the political question doctrine would support the view that the courts ought not to review extraterritorial assertions of federal power.

The political question doctrine, however, does not extend this far. First, note that the doctrine has not prevented courts from questioning congressional grants of judicial jurisdiction under the fifth amendment. ${ }^{107}$ Moreover, the subject of extraterritoriality is not the sort of issue that ought to be denied judicial review. Unlike decisions whether to wage war or recognize foreign governments, decisions about legislative jurisdiction are the sorts of decisions courts are accustomed to making. Indeed, the rules of extraterritorial application presently under attack are of judicial origin, although phrased as a matter of statutory construction. Therefore, the "lack of judicially manageable standards" argument which has pointed towards the existence of a political question in other contexts ${ }^{108}$ is simply not pertinent to judicial review of legislative jurisdiction.

Furthermore, the posture of cases involving the issue of legislative jurisdiction differs from the posture of most cases in which political questions have been found. Where a plaintiff attempts a constitutional challenge to an ongoing program, a court can declare the existence of a political question and leave the situation in the status quo ante by simply refusing to intervene. But a person seeking judicial review of assertions of legislative jurisdiction is typically already involved in a judicial proceeding as a defendant. A court cannot simply refuse to become involved; if it finds a political question, it is obliged to apply American law and effectuate a potentially unconstitutional result. This posture directly implicates the argument that Justice Marshall made for the existence of judicial review: If a court becomes involved in applying a law, then it is obliged also to assess its constitutionality. ${ }^{109}$

Along these lines, it may be relevant that in the international context the political question doctrine has proven most potent with respect to challenges based upon either separation of powers or lack of an affirmative grant of congressional authority in the Constitution. Thus, Henkin's discussion of the political question doctrine in Foreign Affairs and the Constitution recognizes that foreign affairs issues are supposedly typical examples of political questions. ${ }^{10}$ Most such examples, however, deal with problems of whether some particular branch of government has the affirmative power to take some particular action. Henkin adds that the courts are not likely to avoid challenges to

106. Redish, Judicial Review and the "Political Question," 79 Nw. L. Rev. 1031 (1984) (Citing Crockett v. Reagan, 720 F.2d 1355 (D.C. Cir. 1983) (per curiam), cert. denied, 467 U.S. 1251 (1984), as a recent example of the federal courts' refusal to consider the legality of the President's activities in Nicaragua.).

107. Kramer Motors, Inc. v. British Leyland, Ltd., 628 F.2d 1175 (9th Cir. 1980); Paulson Inv. Co. v. Norbay Sec., Inc., 603 F. Supp. 615 (D. Or. 1984); Staffin v. Greenberg, 509 F. Supp. 825, 831, 832 (E.D. Pa. 1981); Alco Standard Corp. v. Benalal, 345 F. Supp. 14, 24, 25 (E.D. Pa. 1972); Oxford First Corp. v. PNC Liquidating Corp., 372 F. Supp. 191, 198-208 (E.D. Pa. 1974).

108. See Baker v. Carr, 369 U.S. 186 (1962): L. BRILMayer, supra note 13.

109. Marbury v. Madison, 5 U.S. (1 Cranch) 137 (1803).

110. L. Henkin, supra note 105, at 210. 
actions alleged to violate individual rights."' Although challenges to extraterritorial authority are in some sense related to the issue of Congress' affirmative power, ${ }^{11}$ they are also appropriately viewed as claims of individual rights. Thus, it seems that assertions of legislative jurisdiction are not shielded by the political question doctrine.

The fact that a court should not defer completely to Congress under the political question doctrine does not speak to the question of the proper standard of review. In other international contexts implicating individual rights, the Court has weighed congressional evaluations of national interest heavily in determining whether the challenged action passes constitutional muster. ${ }^{113}$ This suggests, for instance, that if Congress made findings of fact about the likelihood of effects in the United States or about the importance of market competition, these might be entitled to great deference. This argument, however, merely counsels substantive deference to congressional determinations; it does not mandate complete judicial refusal to address the issues.

2. Does the Constitution Protect Aliens Acting Abroad? Another argument suggesting that constitutional scrutiny might be inappropriate is the argument that the due process clause does not protect aliens acting abroad. It is clear that aliens are protected by the due process clause and other protections while they are in the United States, ${ }^{114}$ although in certain circumstances their rights under the fifth amendment are subordinated to the congressional power to regulate immigration and naturalization. ${ }^{115}$ What is less clear is whether nonresident aliens are protected while they act abroad; arguably they are not.

The applicability of the due process clause to aliens acting abroad may be irrelevant. The due process clause need not apply directly to the activities that occurred abroad; instead it applies to a local occurrence, namely to the litigation underway in U.S. courts. American courts ought not to deprive an individual of life, liberty, or property without due process of law, which they would do if they overextended American law. It is local litigation that triggers the constitutional protection.

The point may be illustrated by analogy to another type of due process problem, namely the enforcement of a judgment rendered without judicial jurisdiction. If an American court attempts to adjudicate a controversy with no American elements, the cases cited earlier suggest that this would violate the due process limitations of the fifth and fourteenth amendments. It would

111. Id. at $210,216$.

112. This is because a nexus with the United States is necessary to empower Congress to regulate; but contrast the challenges discussed in the text, infra following note 121 , which are based purely on the lack of any affirmative grant of power in the Constitution.

113. L. Henkin, supra note 105, at 252 (contours of individual rights different in international context because of national policy and interest as defined by Congress).

114. See generally L. TRiBe, American Constitutional Law $\$ \$ 16-22$ (1978) (discrimination against resident aliens).

115. Fiallo v. Bell, 430 U.S. 787, $792-99$ (1977). 
apparently not matter that the defendant was an alien, nor that the activity in question occurred outside the United States. Indeed, it is because of the absence of local elements that due process would be violated. The local element to which due process attaches is the litigation.

Similarly, a defendant owning property in the United States might resist enforcement of a foreign judgment on the grounds that the foreign court lacked jurisdiction. If the American court refused to recognize the judgment on these grounds, the reason would be that in recognizing such a judgment it would violate due process. ${ }^{116}$ The court need not claim that the due process clause "applied" directly to the foreign cause of action, tried in a foreign court against a foreign defendant. It need simply assert that a U.S. court must extend due process to every individual before it. In this sense, the applicability of the Constitution is similar to the applicability of local long arm statutes or choice of law rules. Just as the forum always applies its own rules of choice of law or personal jurisdiction, so it should apply its own constitutional rules of personal jurisdiction or choice of law.

3. Does the Constitution Reach Farther Than a Federal Statute? Perhaps the above response only serves to raise another problem. Consider the awkward posture of a foreign defendant protesting the applicability of federal substantive law. Such a defendant may find it odd to rely upon the United States Constitution. The objection, after all, is that there is insufficient contact between his or her activities and the United States for it to be appropriate to apply American law. Would it not then seem anomalous to claim protection under due process principles? The defense seems selfcontradictory because it claims both that American law applies and that there is insufficient connection for American law to apply. Would not the more logical basis for the defendant's argument be international law, to which the defendant admits being subject?

This argument is somewhat different than the usual problem about whether the Constitution applies to activities occurring abroad. In the usual context, the alien's constitutional argument is not self-contradictory in the same way. For example, assume that an alien criminal defendant wishes to protest the introduction into evidence of the results of American surveillance abroad. This would raise a question about whether the Constitution applies to searches and seizures taking place outside U.S. territorial boundaries. ${ }^{117}$ In so claiming protection, the defendant does not undercut his or her own substantive challenge. The substantive challenge is to the surveillance; he or she can argue in favor of the applicability of American law without taking a self-contradictory position.

116. Koster v. Automark Indus., Inc., 640 F.2d 77 (7th Cir. 1981); Corporacion Salvadorena v. Injection Footwear Corp., 533 F. Supp. 290 (S.D. Fla. 1982); Boivin v. Talcott, 102 F. Supp. 979 (N.D. Ohio 1951).

117. See, e.g., United States v. Toscanino, 500 F.2d 267 (2d Cir. 1974). 
But the defendant who is challenging the extraterritorial application of a federal statute does risk an apparent self-contradiction. He or she argues that some American law does apply (the Constitution) and therefore other American law (the statute) does not apply. This is different from the position of the criminal defendant, who merely argues that American law does apply, and therefore surveillance is improper. It is only when the Constitution is relied upon as the source of a choice of law protection that this difficulty arises.

While this problem potentially provides a great deal of intellectual amusement for conflict of laws professors, it cannot be taken seriously. A court applies its own choice of law rules, so it is to be expected that it would recognize its own constitutional limitations. Furthermore, if the defendant risks self-contradiction in opposing the application of an American statute on the grounds of American law, the plaintiff is equally at risk. How can the plaintiff argue that the American statute applies, but that the United States Constitution does not? All in all, the defendant has the far stronger position. It seems more likely that the Constitution reaches further than a federal statute than that the federal statute reaches further than the Constitution. If the plaintiff relies on federal law, there is no good reason not to apply federal constitutional limitations also.

IV

\section{New Directions}

Each of these arguments-that international conflicts has reached a methodological dead end and that the Constitution ought to play a more prominent role-suggests new directions for choice of law. The first is the basis for analysis in terms of federal common law; the second calls for an inquiry into what limitations the federal Constitution might create.

\section{A. Federal Common Law}

It is time to recognize that the rules for the applicability of American law internationally are judicial constructs. Admittedly, judicial preferences are subordinated to congressional will when a statutory preference can be discerned. But this does not mean that the answers to all such issues can be found in the statutes themselves. Statutory construction, under some circumstances, is a fiction. Judges rely on international law and on their own views of sound policy when there is no other way to resolve cases. This means that criticism of existing rules of statutory reach should not be characterized as disagreement with "congressional will" or even "American interests." Instead, it may be disagreement over what American interests consist of, and an attempt to refine what a reasonable Congress would have wanted under the circumstances. Presumptions of territoriality, respect for traditional principles of international law, and deference to the interests of other countries are as appropriate at this stage as at the initial formulation of a choice of law rule. 
Calling this body of rules and principles "federal common law" emphasizes two things. First, it is judge-made law; therefore it need not be permitted to become rigid. Continued flexibility is legitimate and appropriate. Second, it is federal, not state, law.

While the latter point may be obvious, it should not be taken for granted. There are two reasons why such law should be federal. One is that the substantive law whose reach must be decided is federal law. Courts, both state and federal, should use federal choice of law rules to decide the scope of a federal substantive law, just as the federal courts use state choice of law rules when applying state substantive law. ${ }^{118} \mathrm{~A}$ second reason is that the issue is one of international relations, and international law is typically treated as federal law. Indeed, state law that impacts on international relations has on numerous occasions been invalidated because in such issues the United States must "speak with a single voice." 119 The Supreme Court has recently hinted that "foreign relations policies" might bear on assertions of state court jurisdiction, which supports the analogous argument that there are foreign relations limits on state choice of law. ${ }^{120}$ This rationale is rather different from the one based upon the federal nature of the cause of action. Not only is it theoretically different, it may give different results in certain fact patterns. In particular, the "international relations" rationale might also apply when a state law competed with the law of a foreign nation. As discussed earlier, such conflicts have to this point been dealt with according to state choice of law rules. ${ }^{121}$

It is not at all clear that conflicts between state law and the law of a foreign nation ought to be dealt with solely as a matter of state law. True, to this date the major sources of friction with foreign countries have involved applications of federal law and not state law. State causes of action have as great a potential for friction as federal ones, however, and this potential has begun to materialize. The Bhopal litigation, for example, demonstrates the international ramifications of state law litigation. The question of what law ought to be applied, instead of whether the case ought to be heard in an American court at all, potentially provokes as much controversy as any conflict between federal law and the law of another nation. In addition, the federal discovery rules that foreign nations have found so irksome are equally likely to cause problems where a state provides the substantive law.

The likely increasing numbers of state law cases (particularly products liability cases) with substantial foreign policy overtones militates against leaving issues of adjudicative and legislative jurisdiction entirely to the states. It is not simply that states may be inclined to overreach; constitutional limitations might be adequate to control that problem. Rather, there are

118. Klaxon Co. v. Stentor Elec. Mfg., 313 U.S. 487 (1941).

119. Japan Line, Ltd. v. Los Angeles, 441 U.S. 434 (1979); Zschernig v. Miller, 389 U.S. 429

(1968); Hines v. Davidowitz, 312 U.S. 52 (1941).

120. Asahi Metal Indus. Co. v. Superior Ct., 55 U.S.L.W. 4197, 4200 (1987).

121. See supra text accompanying notes 6,14 . 
tremendous difficulties inherent in subjecting foreign defendants to the jurisdictional rules of fifty different sovereigns. As this dilemma comes to be more widely appreciated, political pressure may mount either for treaties that would preempt state law on such issues or, failing that, for the application of federal jurisdictional standards in state substantive law litigation.

\section{B. The Role of the Constitution}

This article is not an appropriate place for an exhaustive analysis of the possible contours of the constitutional limits on the application of federal law to transnational disputes. That would be an article, or more likely several, in and of itself. Nevertheless, a few observations may be of interest.

There are two different ways in which the application of federal law to a transnational dispute might run afoul of the Constitution. First, there may not be an affirmative basis in the Constitution for regulation of the particular issue in question. Federal power consists of certain enumerated functions, including, for example, the regulation of international commerce. ${ }^{122}$ Second, while there may be a basis for regulation, imposing the regulation would violate the defendant's individual rights. In particular, imposition of federal law without a sufficient nexus for regulation might violate the fifth amendment's due process guarantee.

These are not merely two different ways of saying the same thing. To appreciate this point, contrast the limits on state law with the limits on federal law. The limits on the application of state law are all of the second type: Because states have residual power, it is unnecessary for them to find an affirmative basis for their actions. The federal government, to the contrary, must find a basis for its acts in an enumerated power. Unless a state law contradicts one of the enumerated limits imposed by the Constitution or is preempted by a valid federal law, the state law is valid regardless of whether the state has cited any affirmative basis for legislating.

Restrictions imposed on the federal government under this reasoning do not seem very burdensome. Under commerce clause analysis in a domestic context, the powers of Congress are exceedingly broad. ${ }^{123}$ Under commerce clause analysis in an international context, they presumably are equally broad. But it still must be international commerce. Thus, if a transaction were purely internal to a single foreign nation, it might be argued that Congress possessed no affirmative power to legislate. One suspects that this line of reasoning, while interesting in theory, is likely to result in the invalidation of very few laws because the scope of congressional power is potentially so broad.

Of greater practical importance would be the other type of limitation. Even where Congress has some basis for regulation, application of its laws may still violate due process. One reason would be the lack of a sufficient nexus between the controversy and the United States. This problem is

122. U.S. Const. art. I, \& 8, cl. 3.

123. See generally L. TRIBE, supra note $114, \S \S 5-4$ to 5-6. 
comparable to the usual due process limits on a state applying its law to a transnational case. ${ }^{124}$ The same test applicable to state choice of law under the due process clause might be used here: "[A] significant aggregation of contacts, creating interests." 125 Another reason might be the imposition of inconsistent obligations. It can be argued that a violation of due process occurs when a U.S. court orders a defendant to engage in actions that would result in criminal or civil sanctions in another state. Discovery rules provide the most frequent example of this problem, although there are other examples such as the imposition of export restrictions. ${ }^{126}$

\section{CONCLUSION}

It is entirely possible that none of these subtleties will ever prove necessary to explore. So far, the courts have proceeded quite happily while remaining oblivious to these issues. Accordingly, counsel for foreign defendants have focused attention on issues of proven importance. Even law professors have done well enough without these added complications.

If one stops to think about these rarified theoretical observations, however, one might come to wonder about some things that are otherwise taken for granted. The methodological status of choice of law rules ultimately makes a difference, because it influences a court's view of its proper role in the international arena. The choice between state and federal law to resolve these issues likewise poses a theoretical issue with practical dimensions; this choice dictates whether a state court deciding the applicability of state law must follow federal precedents on the applicability of federal law, and vice versa. The constitutional issues are of comparable importance in that they could pose outer limits on Congress' power.

If these questions do provoke interest and gain the attention of courts and litigators, then perhaps we will get some answers to them in the coming years. Certainly, it should be expected at least that cases involving private international law will continue to be a source of controversy and scholarly analysis, however the issues are phrased.

124. See, e.g., Home Ins. Co. v. Dick, 281 U.S. 397 (1930).

125. Allstate Ins. Co. v. Hague, 449 U.S. 302, 308,313 (1981) (plurality opinion).

126. See, e.g., Dresser Indus., Inc. v. Baldridge, 549 F. Supp. 108 (D.D.C. 1982). 